\section{Challenge and Response in African Higher Education}

\section{David Court}

David Court is on the staff of the World Bank. Address: World Bank, 1818 H St. NW, Washington D.C. 20433, USA.

A high degree of consensus exists among educational leaders and scholars in Africa about the challenges facing the development of higher education-in countries not suffering from civil turmoil. The list is easily drawn:

- to move from an elite to a mass system, while retaining quality, in a situation of resource constraints;

- to move from insularity to partnerships-national, regional, and international - with other types of producers of higher education;

- to take advantage of changes in knowledge generation through linkages outside the traditional domain of higher education;

- to achieve institutional diversity in a situation where each institution cannot provide everything;

- to improve selection and certification processes and linkages to the rest of the system;

- to make higher education more responsive to society;

- to accelerate the participation of female students and staff to a point of gender parity; and

- to enhance the interest of all students in mathematics and science.

\section{The Overarching Challenge}

All these and other challenges (including the effect of AIDS on students and teachers) can be found among the higher education systems of different countries in Africa. They can be subsumed under one major challenge: how to transcend the historical legacy of the colonial university through the introduction of new purposes, practices, and styles of higher education.

In two respects, universities have not been very successful at overcoming their past. First, they have found it difficult to create and nurture a new vision or mission to provide a reason for their existence. In the years immediately after independence the common vision and purpose centered on the function of undergraduate teaching and preparation for positions in the public sector. Later, there was some agreement on the idea of the "development university," associated with the thinking of Julius Nyerere, but more recently, this concept, too, was abandoned or discredited. What has been lost by universities is their ability to retain an incentive system that upholds the scholarly purpose and vision of the university as an intellectual community involved in teaching, research, and the production of knowledge.

A major reason for this loss is that universities have not had the autonomy to exercise their vision. The university's self concept of what it might be has been hijacked by government and to some extent by external assistance agencies. Governments have exercised tight control through their funding and legal monopoly and at times through more direct politicization and intimidation of institutions. Assistance agencies have also had a distorting effect on the autonomy of the university, particularly when they have made the provision of funds conditional upon the achievement of social or developmental objectives external to the institutions themselves that they might be singularly ill-equipped to achieve.

A second part of the legacy that has encumbered universities is their inability to develop a system of financing not largely dependent on the state. Africa inherited a university model in which the state paid all costs and has found it difficult to get away from this model. Dependence on the state makes it impossible for a nation seeking highquality higher education to have anything more than a small elitist university. Several African countries where the state subsidy to higher education has remained constant at the limit of what the country could afford have seen student numbers increase disproportionately to resources, the physical plant deteriorate, morale plummet, faculty depart, quality sink, and research all but disappear. A classic case of this situation occurred a few years ago in Kenya.

Readers of this newsletter are familiar with the sense of despair and pessimism that has pervaded higher education over the past 15 years. Numerous articles have bemoaned the effect of the economic crisis, government and donor mismanagement, the sheer pressure of social demand on inadequate facilities, overstretched teachers, depleted laboratories, and dysfunctional institutions. Yet amidst the talk, and indeed the reality, of the deteriorating situation, declining quality, and brain drain, new trends and initiatives are discernible.

The changes are occurring both inside and outside universities and give grounds for cautious optimism about the possibility of regaining quality, relevance, and ultimately new purpose for higher education on the continent. These trends are scattered, modest, but real and, most importantly, have generalizable properties and potential. Together, they amount to a loosening up of the system, with more space for autonomous experimentation, models that are less homogeneous or monolithic, greater diversity - in short, a more hospitable context for innovation.

\section{Internal Trends and Initiatives}

Privatization. Perhaps the most powerful force in higher education today is that of privatization. Governments are realizing that alone they cannot finance the existing demand for higher education. Uganda offers a startlingly instructive example of the power of private funds. Five years ago, Makerere University had virtually no fee-paying students; today such 
students make up 60 percent of total enrollments. The influx of private students, along with the creation of commercial units and an associated consultancy company, has enabled the university to more than offset a declining government subvention. These funds have been devoted to faculty development, staff salary supplementation, general maintenance, and library enrichment, which have served to rejuvenate the academic life of the institution. In Uganda, as well as in Tanzania and Kenya, private universities are springing up and offering competition, diversification, and possibilities for innovation. Privatization is not a panacea-governments cannot abdicate control over higher education to the market-and while it raises equity issues, it is giving some universities the resources to reorganize themselves.

\section{Universities have not been very success- ful at overcoming their past.}

Strategic plans and improved governance. Financial reform in universities has been accompanied by large-scale administrative restructuring, usually based on strategic plans and professional management systems, and leading to more decentralized administration in individual institutions. At the national level, changes in the antiquated legislation in many countries will increase the autonomy of institutions of higher education to manage their own affairs.

Specialization and diversification. As part of a new realism, universities are evolving as parts of a diversified national system of higher education, with growing acceptance of an internal institutional division of labor. These changes are permitting institutions to specialize in areas where they have depth, without feeling it essential to duplicate all faculties of a conventional university.

Regional programs. On a regional basis there is also an increasing willingness among universities to utilize programs and degrees that draw on the strength of participating institutions. The African Economic Research Consortium, which links seven engineering faculties in eastern and southern Africa, are examples of this trend.

Female participation. At last, there is serious recognition by some governments and universities of the need to increase the numbers of women students, faculty, and administrators. This signifies not just a concession to a notion of equity but an understanding that this will influence for the better changes in the quality, practice, and structure of universities - as has occurred already for the University of Cape Town.

New technologies. The use of new technologies is increasingly evident at leading African universities. They include not simply new methods of storing and disseminating knowledge and improved forms of teaching and learning, but de- veloping whole new ways of thinking about higher education-its scale, scope, and appearance. Distance education and the African Virtual University are not substitutes for faceto-face approaches but are important complements and enrichments.

\section{External Environment}

Finally three changes in the external environment of universities in Africa are worth mentioning.

Democratization. Where the spread of democratic forms has happened, more-open societies are creating an atmosphere favorable to more lively and experimental universities. Free speech, a critical press, parliamentary parties, public debate, the absence of informers, and so forth all help to create a climate where universities can be more imaginative, courageous, and relevant. In welcoming this trend we also need to be mindful of countries such as Somalia, Sierra Leone, Rwanda, and others where the minimum administrative integrity for any kind of university functioning does not exist.

South Africa. The emergence of South Africa onto the African higher education scene has enormous significance and potential for the rest of the continent. South Africa has its own problems to address, and cannot be looked to for fixing or salvaging institutions to the north. But it also has world-class universities that do receive students from further north, and it sends out teachers. Interaction with the rest of the continent can in itself be a most valuable source of new ideas and standards.

\section{Perhaps the most powerful force in higher education today is that of privatization.}

Assistance agency interest. One other change in the external environment is the renewed interest of external assistance agencies in the education sector as a whole, including higher education. Historically, the record of external assistance to higher education has been mixed, but hopefully the relative disinterest of the last several years will be followed by a more enlightened partnership in support of the best in African higher education

These trends just mentioned are scattered and fragile and are not all guided by a single objective or vision. Change is not going to be a big bang revolution but rather a process of evolution, as institutions set examples for emulation and experimentation and countries energetically look for change rather than resist it. If African economies grow, stability is maintained, and governments keep at arm's length, the year 2000 may witness a dramatic improvement in the health of higher education on the African continent. 